\title{
Developing a Strong HRM System: The Role of Line Managers
}

\author{
$\mathrm{Na} \mathrm{Fu}^{* 1}$, Stephen Keating ${ }^{2}$ and Marian Crowley-Henry ${ }^{3}$ \\ ${ }^{1}$ Trinity Business School, the University of Dublin, Ireland \\ ${ }^{2}$ Revenue Tower Lead, Ingersoll Rand, Ireland \\ ${ }^{3}$ Maynooth University School of Business, Maynooth University, Ireland
}

Submission: November 10, 2018; Published: February 08, 2019

"Corresponding author: Na Fu, Trinity Business School, Trinity College Dublin, the University of Dublin, Dublin 2, Ireland

\begin{abstract}
The aim of this paper is to examine the line manager's role in developing a strong human resource management (HRM) system which is distinctive, consistent and consensual. This paper explores the process and outcomes of the line managers implementation of a high performance HRM system in an Irish knowledge intensive firm.
\end{abstract}

Design/methodology/approach: This study is based on interviews with senior management, HR director, line managers and front-line employees in an Irish organization.

Findings: The findings show support for the important role of line managers in implementing HRM systems to develop a strong HRM system in the organization. However, there is inconsistency across line managers' communication and implementation of the new system resulted in confusion and frustration among their respective subordinates.

Practical implications: HRM professionals need to be aware of the important role of line managers in promoting a strong HRM system in the organization. In a knowledge intensive firm, where agility and flexibility are essential, different departments may require different nuances to an HRM initiative.

Originality/value: This study contributes to a better understanding of the HRM implementation process in a knowledge-intensive firm in Ireland, by using the HRM system strength model as the theoretical basis for analysis and discussion.

Keywords: HRM System Strength; HRM, Case Study; Knowledge-Intensive Firm; HRM Implementation

\section{Introduction}

During the past few decades, the impact of strategic HRM (SHRM) practices on organizational performance [1,2], in both manufacturing and knowledge intensive firms, has gained extensive research attention. For example, high performance work systems (HPWS) including selective recruitment, extensive training and development programmes, competitive compensation and benefit packages, participation and information sharing, have been widely found to positively link to firm performance. These 'intended' HRM practices consist of the HRM policies and practices designed by the HR professionals in order to align with business strategy [3-5].

Recently, scholars argue that it is not enough to have these practices or policies in place rhetorically; only when these practices are implemented, mostly by line managers, can these practices create value for the organization [6]. This is when the 'intended' HRM practices become the 'actual HRM' practices [5]. In implementing HRM strategies, line managers have the dual responsibility of managing individual employees' work-related activities and playing a vital role in transforming strategic human resource management initiatives into practice in the organization [6-12].

They are both 'employee advocate' and 'HRM business partner' [13]. The increasing HRM responsibility facing line managers is noted in the literature Edgar, Geare and O'Kane (2015) Larsen and Brewster (2003). However, how line managers implement HRM has not been given enough attention Brewster et al. (2013). In order to enable a smooth transition from organizational to employee perceived HRM [5], organizations need a strong HRM system, where all levels of employees share collective perceptions, attitudes and behaviors [14]. To build a strong HRM system and shape employees' perceptions of the new HRM system, line managers are the key agents in their capacity to send HRM messages and to implement HRM practices $[8,9,15]$.

This paper examines how different intra-organizational players - senior managers, the HRM manager, line managers and front-line knowledge workers - perceive the implementation process of a new HRM system. The role of each of these in the implementation and 'actual HRM' of a new HRM system, in this 
case, a high-performance work system (HPWS) in a knowledgeintensive firm (KIF) in Ireland, is analyzed, particularly focusing on the line manager's role and how this is perceived. The study contributes to the research gap on the HRM implementation process by applying the HRM system strength model [14] to qualitative interview transcripts collected in an international KIF based in Ireland. Our study integrates views from multiple stakeholders in order to ascertain gaps in the distinctiveness, consistency and consensus features of a strong HRM system [14]. In particular, the relationship between the line managers and the employees is considered, in line with studies by Bos-Nehles and Bondarouk [15], Bos-Nehles, Van Riemsdijk \& Kees Looise [8], and Kilroy \& Dundon [9], that explored the employees' perceptions of line managers' intentions, performance and styles.

\section{Research Context: Knowledge-Intensive Firms}

Knowledge-intensive firms (KIFs) have been defined as those firms where work is primarily intellectual and analytically taskbased; where jobs are not highly routinized and involve some degree of creativity and adaptation to specific circumstances; and where the workforce consists of well-educated and qualified employees to carry out the tasks and jobs successfully [16-18]. Examples of KIFs are high-technology, R\&D-centred companies, management and IT consulting firms. KIFs operate in a dynamic and highly competitive environment Alvesson (1995) (2001). Products and services are more complex, and the rate of competition has accelerated, with shorter life-cycles [19] which require constant adaptability. The telecommunications industry is a prime example of an industry where competition has accelerated.

The increasing use of internet-based calls, e.g. Skype, Voip (voice over IP), have raised the pressure for the telecommunications industry that provide landline and mobile phone services. In addition, customers' phone usage has evolved from making phone calls to sending texts/messages and to "eating data", which creates new opportunities and challenges for service quality, and new pricing models. How telecommunications operators cope with these challenges and achieve competitive advantage is a timely question, not only for the telecommunications industry, but also for other knowledge-intensive industries. This paper explores data from an Irish case study organization within the telecommunications industry.

\section{Conceptual Framework: Strong HRM System}

A strong HRM system can "help explain "how" HRM practices lead to outcomes the organization desires' [14]. In linking organizational climate and organizational effectiveness, Bowen \& Ostroff [14] HRM system strength construct presents three main features which together will impact upon employees' shared perceptions of the organizational climate, in turn influencing organizational effectiveness. These three main features are: distinctiveness, consistency and consensus. (Table 1) presents and describes the main features and their respective meta-features for a strong HRM system based on Table 1.

Table 1: HRM System Strength Features.

\begin{tabular}{|c|c|c|}
\hline \multicolumn{2}{|c|}{ HRM strength features } & Meaning \\
\hline \multirow{4}{*}{ Distinctiveness } & Visibility & refers to the degree to which these practices are salient and readily observable. \\
\hline & Understandability & refers to a lack of ambiguity and ease of comprehension of HRM practice content. \\
\hline & Legitimacy of authority & $\begin{array}{l}\text { leads individuals to consider submitting to performance expectations as formally sanctioned } \\
\text { behaviours. }\end{array}$ \\
\hline & Relevance & $\begin{array}{l}\text { refers to whether the situation is defined in such a way that individuals see the situation as } \\
\text { relevant to an important goal. }\end{array}$ \\
\hline \multirow{3}{*}{ Consistency } & Instrumentality & $\begin{array}{l}\text { refers to establishing an unambiguous perceived cause-effect relationship in reference to the } \\
\text { HRM system's desired content-focused behaviours and associated employee consequences. }\end{array}$ \\
\hline & Validity & $\begin{array}{c}\text { is important because message recipients attempt to determine the validity of a message in } \\
\text { making attributions. }\end{array}$ \\
\hline & Consistent HRM messages & These convey compatibility and stability in the signals sent by the HRM practices. \\
\hline \multirow[t]{2}{*}{ Consensus } & Fairness & $\begin{array}{l}\text { is a composite of employees' perceptions of whether HRM practices adhere to the principles } \\
\text { of delivering three dimensions of justice: distributive, procedural, and interactional These } \\
\text { convey compatibility and stability in the signals sent by the HRM practices? }\end{array}$ \\
\hline & Agreement & Agreement among these message senders helps promote consensus among employees. \\
\hline
\end{tabular}

\section{HRM Distinctiveness}

Four meta-features form the distinctiveness feature of a strong HRM system, i.e. visibility, understandability, legitimacy of authority, and relevance [14]. Visibility refers to HRM practices that are salient and readily observable for employees. Understandability refers to a lack of ambiguity and ease of comprehension of HRM practice content. Legitimacy of authority leads individuals to consider submitting to performance expectations as formally sanctioned behaviors. Relevance refers to whether the situation is defined in such a way that individuals see the situation as relevant to an important goal.

\section{HRM Consistency}

Consistency, according to Bowen \& Ostroff [14], mainly refers to establishing consistent relationships. Consistency of HRM has three meta-features: instrumentality, validity, and consistent HRM messages. Instrumentality refers to establishing an unambiguous perceived cause - effect relationship in relation to the HRM system's desired content-focused behaviours and associated 


\section{Annals of Social Sciences \& Management studies}

employee consequences. Validity means that the HRM practices can achieve the goals planned during the designing stage of such HRM practices. Consistent HRM messages refer to the stability in the signals sent by the HRM practices.

\section{HRM Consensus}

Consensus of HRM practices refers to the agreement among employees regarding the intended targets of the HRM system. Its two meta-features are fairness and agreement. Fairness of the HRM system is a composite of employees' perceptions of whether HRM practices adhere to the principles of delivering three dimensions of justice: distributive, procedural, and interactional justice [20]. Distributive justice concerns about the equality of the outcome [21]. Procedural justice relates to the process or mechanisms through which outcomes are decided rather than the actual outcomes [22,23]. Interactional justice is concerned with the interpersonal treatment people receive during the implementation of the procedures [24].

Heffernan \& Dundon [25] investigated employee perceptions of the fairness of HR practices associated with the high-performance work systems model. In their quantitative survey across three organizations in Ireland, employee perceptions of distributive, procedural and interactional justice mediated the relationship between high-performance work systems and job satisfaction, affective commitment and work pressure. The other metafeature of consensus is agreement which refers to the agreement among principal HRM decision makers, e.g. HR professionals, top management team, and line managers. We expected this aspect, agreement, to be particularly interesting in our analysis of the multi-stakeholder qualitative interviews with senior managers, the HR director, line managers and employees in a KIF in Ireland.

\section{Line Managers' Role in HRM Implementation Towards Building HRM System Strength}

The majority of SHRM research has focused on organizational HRM policies and practices [26]. Some researchers argue that the focus on the design of HRM policies and practices is not enough, as it is only when these are implemented appropriately that they can create value for organizations [5]. Wright and Nishii [6] have labelled the implementation of HRM practices as 'actual HRM'. The key agents for implementing HRM are the line managers who interact with front line employees in a frequent and timely

Table 2: Role of line managers in fostering HRM system strength. manner. Line managers have HRM responsibilities Alfes et al. (2013) by virtue of their frequent and direct interactions with their team members and subordinates.

In project-based organisations, for instance, the project managers, supervisors or assignment managers are not only responsible for project-related work (e.g. analyzing project needs, allocating workload, monitoring project progress, completing project reports), but also are responsible for team management (e.g. analyzing training needs, informing subordinates of training opportunities, managing individual performance, providing feedback, promoting participation) Keegan, Huemann and Turner (2012). The line manager's role in the implementation of people management practices is of critical importance in shaping employees' perceptions, experience of and attitudes towards their work and organization [27]. A collective perception of HRM practice is expected where employees share similar experience of the work practices and have the behaviors desired by their respective organizations, i.e. a strong HRM system [14]. For the organization and senior managers, line managers are important, as they are the implementers of the organization's HR policies and practices, e.g. treating employees as resources and/or caring about their personal experience at work [6].

For employees, line managers have been shown to play an important role in how employees experience their work [28-31]. How line managers implement HRM practices has implications for how employees perceive and align with those practices. In other words, the strength of the HRM system is heavily dependent on the line manager's role. The line manager's key role in the implementation of HRM has received increasing attention due to their relevance in creating a strong HRM system.

For example, based on a European dataset, Larsen and Brewster (2003) found clear evidence of a greater assignment of HRM responsibilities to line managers. Other studies show that line managers play an important role in managing employee learning and development Gibb (2003), attendance Hadjisolomou (2015), voice Townsend and Loudoun (2015), conflict Saundry, Jones and Wibberley (2015), and knowledge sharing MacNeil (2003). These studies have provided valuable insights on the impact of line managers' implementation of HRM on different employee and organizational outcomes. (Table 2) shows the expected line managers' roles in promoting HRM system strength.

\begin{tabular}{|c|c|c|}
\hline \multirow{4}{*}{ Distinctiveness } & Visibility & Role of line managers - Actual HRM \\
\cline { 2 - 3 } & Understandability & Making sure that employees understand the HR practices. \\
\cline { 2 - 3 } & Legitimacy of authority & Following the instructions from the top management team and HR department \\
\cline { 2 - 3 } Consistency & Relevance & Enacting employee-focused HR practices, e.g. career development-based training. \\
\cline { 2 - 3 } & Instrumentality & Showing the causal link between top performance and rewards. \\
\cline { 2 - 3 } & Validity & Communicating with the HR department about the feasibility of HR practices. \\
\hline \multirow{2}{*}{ Consensus } & Fairness & Understanding the HRM message and sending it to the employees. \\
\cline { 2 - 3 } & Agreement & Supporting the decisions made by the top management team and HR department. \\
\hline
\end{tabular}


For the distinctiveness of the HRM system, line managers play an important role in informing employees about HR practices (visibility), explaining how these HR practices work (understandability), following the instructions from the top management and HR department (legitimacy of authority), and demonstrating care for everyone, e.g. providing performance feedback (relevance). For the consistency of the HRM system, line managers need to show the causal link between top performance and rewards (instrumentality). For example, line managers would seek the opportunity to provide employees with recognition or reward when they perform their work well or when they have improved their work efficiency.

Line managers need to provide support for employees' career development [32]. In addition, to achieve the validity of HR practices, line managers need to communicate with the HR department about the feasibility of the HR practices. In sending consistent HRM messages over time, line managers need to understand these messages and send them clearly to employees. As line managers communicate with employees very frequently, they know their subordinates' needs and would be able to find the best way to communicate the message to them more effectively.

The last feature of HRM system strength is consensus including fairness and agreement. Fairness covers distributive, procedural and interactional justice. Research shows that the manager can make a large difference in affecting employees' perceived justice [33]. Line managers take charge of distributing work, content and resources. Their decisions on these aspects are critical in the formation of employees' psychological contract, which is an unwritten contract between employees and employers [34] trust $[35,36]$ and commitment [37]. To ensure distributive justice, line managers should make sure that employees' work gets recognized within and across teams. For procedural justice, line managers should ensure that the resources are distributed openly and fairly. For example, only those better performers receive rewards. For interactional justice, line managers should listen to employees and consider their opinions when making decisions. High agreement requires line managers to understand, accept and promote the specific HR practices among employees.

The focus in this paper is on unpacking the role of the line manager as perceived by the line managers themselves, by the employees (directly reporting to line managers), and by senior managers (to whom the line managers themselves report), as well as the HR Director

\section{Research Method}

\section{Case Organization Context}

We undertook a single case study $[38,39]$ within a knowledgeintensive firm in Ireland, a division of a large multinational organization, where the HRM initiative being implemented by line managers was a change initiative (introducing a highperformance work system throughout the organization). The sample organization, Telecoms1 (pseudonym), is one of Ireland's leading telecommunications companies with over 1.5 million customers. It runs $2 \mathrm{G}$ and $3 \mathrm{G}$ networks in Ireland. It operates a Media mobile marketing division, supports a number MVNO's (Mobile Virtual Network Operators) and is home to an academy for accelerating start-ups.

Telecoms1 employs over 900 people and has a retail network in excess of 70 stores. It has been operating in Ireland for 17 years and is part of an international group. However, despite being a division in a multinational organization, Telecoms1 operates as a standalone business unit in the Irish market, though the parent is the ultimate budget approver and holds responsibility for senior leadership appointments. In being a division in a multinational organization, it could be that practices which are successfully implemented in the Irish division may influence the implementation of similar practices in other country contexts. However, we did not focus on this in our study.

The current CEO was appointed in October 2011 following previous senior positions within the group. Reporting to him are five directorates: Business, Consumer, Marketing and Innovation, HR, Finance \& Technology. After the appointment of the new CEO, Telecoms1 found itself suffering from the effects of the Irish economic collapse, increased market competition and regulation that was reducing revenue streams (roaming, interconnect etc.), resulting in falling profits and market share. In addition, the consumer wanted new devices, demanded new services and technology advances. It was with this backdrop that Telecoms1 introduced a change initiative in 2012, its high-performance work system model, where targets and metrics for employee performance became paramount.

\section{This HPWS Included Six Targets}

a) building organizational resilience

b) delivering unreasonable ambition

c) clarity on what really matters

d) living high standards

e) having a feedback rich culture

f) being decisive and promoting better decisions. The organization's fundamental goal was to become a highperformance organization.

To achieve these targets and the goal, the first key step that the senior leadership team took was to launch a new employee performance management model. This new performance management model asked managers and employees to agree with objectives that focused not only on the traditional whatactions, but also on the how- behaviors. To achieve continuous performance improvement, line managers were asked to evaluate "what" employees have achieved to contribute to the company's objectives as well as "how" consistently the employee had demonstrated behaviors. This study focuses on the design and implementation stages of the new HPWS, and the process of its 
implementation as perceived by senior managers, the HR director, line managers and employees.

\section{Sample and Data Collection}

Telecoms1 has relatively flat organizational structure. The organization includes the senior management teams (including the CEO and HR Director), line managers and front-line employees. The aim of this study was to comprehensively study the line managers' role in implementing HRM practice in the organizations, as experienced and shared by the line managers themselves and by their superiors (senior management and the HR director) and subordinates. Therefore, when designing the study, we firstly mapped out the key organizational stakeholders in this change management initiative. In this context, the designing of the HPWS was led by the senior management team including the HR Director, promoted by senior managers, and implemented by line managers.

Therefore, we decided to select samples from these three groups. The first author contacted all members on the senior management team, and line managers and employees via his network. To capture of implementation of the HPWS, qualitative data was collected from senior management (three Top Management Team Members and the HR Director), line management (three-line managers) and the employees (four front-line employees) via semi-structured interviews and a focus group (with the employees only) in 2014, two years after the change programme had been initiated. Each interview lasted from 30 to 60 minutes. Table 3 presents the interviewees' profile.

Table 3: Interviewees' Profile.

\begin{tabular}{|c|c|c|}
\hline Groups & Title & Profile \\
\hline \multirow{4}{*}{ Senior Management Team } & HR Director & Female 7 years 4 months in the organization \\
\hline & Business Director and Deputy CEO (SM1-AB) & Male 8 years 8 months in the organization \\
\hline & Marketing \& Innovation Director (SM2-EM) & Male 7 years 2 months in the organization \\
\hline & Director of Strategy (SM3-RM) & Male 7 years and 2 months in the organization \\
\hline \multirow{3}{*}{ Line managers } & Head of Finance Customer Operations (LM1-MD) & Female 5 years 2 months in the organization \\
\hline & Senior Financial Controller (LM2-CM) & Female 6 years 10 months in the organization \\
\hline & Fraud \& Security Manager (LM3-DM) & Female 17 years 8 months in the organization \\
\hline \multirow{4}{*}{ Front line employees } & Fraud \& Security Analyst 1 (Employee 1) & Female 17 years in the organization \\
\hline & Fraud \& Security Analyst 2 (Employee 2) & Female 9 years in the organization \\
\hline & Business Change Analyst (Employee 3) & Female 5 years in the organization \\
\hline & AP \& AR Analyst (Employee 4) & Female 2 years in the organization \\
\hline
\end{tabular}

We appreciate that the very limited number of interviews conducted cannot be generalizable to all members of the organization. However, the multi-level snapshot of the interviews conducted provides an overview of the diversity of individual players involved in a change management HPWS and shows how agreement and consensus from Bowen \& Ostroff's [14] HRM system strength framework is most challenging in practice.

The qualitative approach allowed us to gather descriptions of the participants' experience [40]. The participants were able to express their views, opinions and values fully putting them in the position of expert during the interview [41]. Respecting the individual's right to privacy was crucial and at no time anybody was to feel pressurized or coerced into taking part [42]. All participants were assured what they said would be treated confidentially. A topic guide $[43,44]$ was used in the interviews, with all respondents asked to discuss the introduction, implementation and the outcomes of the HPWS.

The interviews were semi-structured, ensuring that all the topics were covered across the organizational levels, but that there was flexibility for the respondents to speak about matters which were not directly addressed on the topic guide [45]. In this way, the semi-structured interview process facilitated the collection of data on the same themes while also enabling an exploration of issues across the respondents [46] on the introduction of the HPWS.

The first author conducted the interviews. His role was to inform the respondents about the purpose of this study, to assure them of the anonymity of the study, and to confirm they were comfortable to answer the questions. The interview was guided by the interview questions. Respondents were given free rein to speak about the topic from their own perspective. During the interviews, respondents often addressed sub-questions in answering on a topic which could enrich our understanding of their perceptions.

\section{Data Analysis}

All interview recordings were transcribed verbatim to retain the integrity of the data [47]. Given that there were three researchers involved in the study (authors), QSR Nvivo (version 10) was used in coding and analyzing the data. This system enabled the researchers to review each other's coding strategies and validate them. The interviews and focus group data explore the nature of the participants' engagement, understanding and actions they took in relation to the HPWS initiative in the organization $[46,48,49]$. During the analysis of the data, the interview transcripts were coded following the Bowen \& Ostroff [14] HRM system strength framework, with the interviews separated out across the intra-organizational levels of senior 


\section{Annals of Social Sciences \& Management studies}

management, line management and employees (Tables 4-6). This allowed us to capture the cross-level variation in terms of how each level perceived the line manager's role in the introduction of the HPWS. The respective transcripts were read several times and coded in line with the nine meta-features under the three dimensions put forward by Bowen and Ostroff [14].

Table 4: HR Director and Senior Managers' Quotes on Implementing HRM.

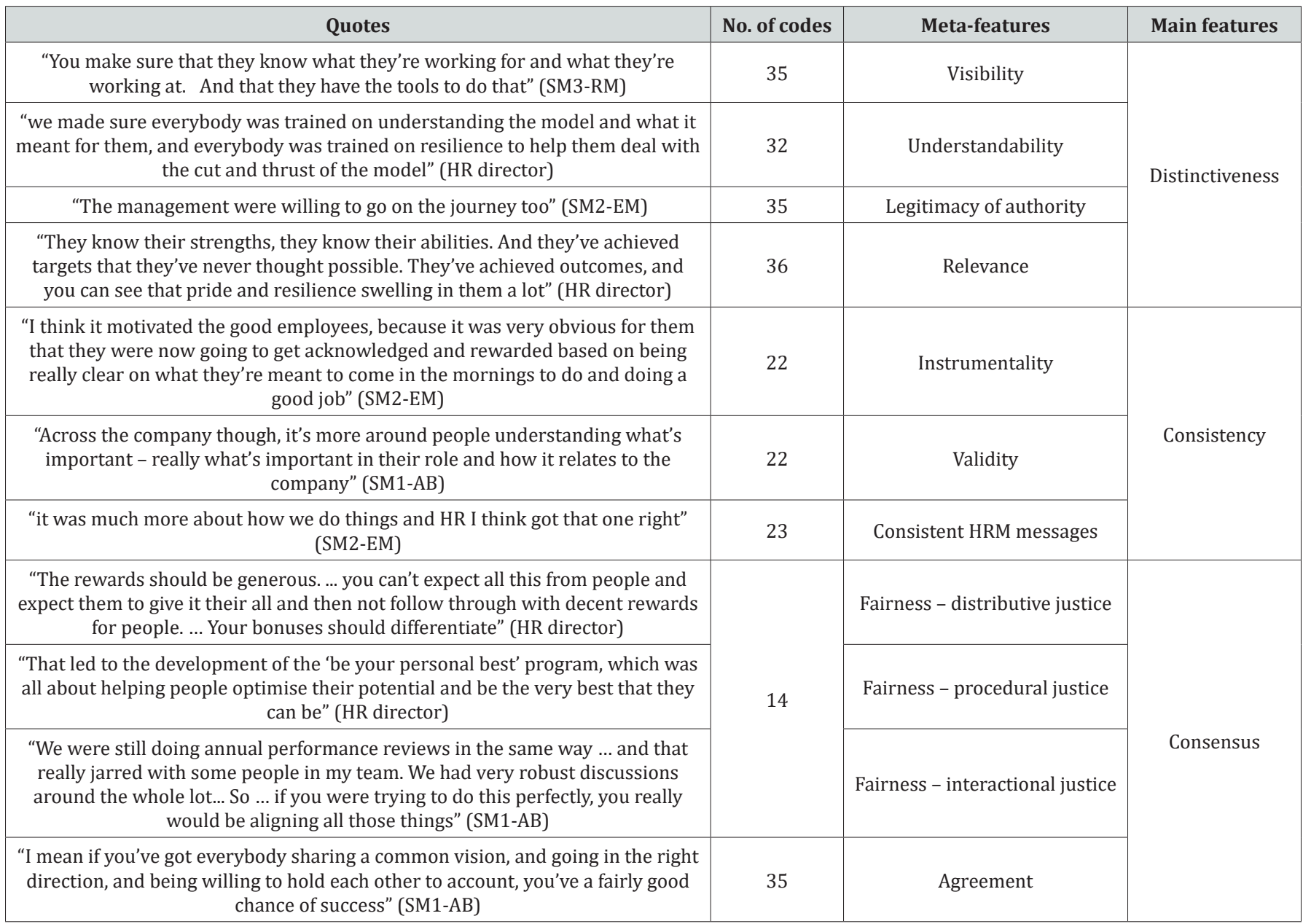

\section{Findings on the Line Manager's Role in Fostering a} Strong HRM System

The need for the change programme in the KIF was outlined previously. The HR Director sums this up as: "I think we had started to accept a certain medal of mediocrity in the business" and a change in the attitude and culture of performance was required. Equally, the CEO (SM1-AB) felt that "at the time the culture was very collaborative, collegiate, and team-focused - all good positive stuff, but frankly maybe a little bit soft. And a little bit tolerant. So, we felt there had to be a change in that...we did feel there had to be a little bit more of an edge to why people were here, you know, what they were doing. And just that culture, that performance really mattered". This distinctive appreciation that a change was required was replicated across levels, with the line managers and employees accepting the need for the change program and the HPWS. As the HR director describes, gaining support from senior management was the catalyst in ensuring the change program would work:

"I knew once I got them the board into the right frame of mind and if they were accepting of the model, then you could probably overcome most challenges after that". In this section we firstly outline the line manager's role, as described by the line managers themselves, in terms of the strength of their implementation of the HPWS in the organization Table 5 provides some example quotes here across the Bowen \& Ostroff [14] HRM system strength model. The richness of the data collected can be seen through the quotes shared here Table 5.

As shown in Table 5, all the three main and nine meta-features of strong HR system were covered by the line managers in our case KIF in Ireland. Indeed, in our analysis across levels, we found that all the features were present across each of the levels, suggesting the foundations of a strong HRM system were present in the organization. However, the legitimacy of authority (under the Consistency dimension), and fairness and agreement (under the Consensus dimension), were included less often in the narratives concerning the HPWS introduction from the line managers.

Line managers acknowledge the drive for change initiatives that needs to come from senior managers and then cascaded down the organization. This support and buy-in from the top are required in order to encourage the line managers to implement 


\section{Annals of Social Sciences \& Management studies}

the HRM model (see following quote): "So this came from the top. I honestly think that this was always going to be [that CEO] wanted changes quickly. So, I think there was drive and ambition from the top of this" (LM1-MD).

Table 5: Line Managers' Quotes on Implementing HRM

\begin{tabular}{|c|c|c|}
\hline Quotes & Meta-features & Main features \\
\hline $\begin{array}{l}\text { "So, it really gave people that clear picture and it made things a lot easier in terms of } \\
\text { messaging things back to individuals because they were very clear up front in terms of } \\
\text { where you were coming from" (LM2-CM) }\end{array}$ & Visibility & Distinctiveness \\
\hline $\begin{array}{l}\text { "I saw a lot of people getting very clear on how they would work - their ways of working. } \\
\text {... It enabled people ... to manage their priorities, manage their goals and actually manage } \\
\text { their stakeholders more effectively as well" (LM2-CM) }\end{array}$ & Understandability & \\
\hline $\begin{array}{l}\text { "So, this came from the top. ...I think there was drive and ambition from the top of this" } \\
\text { (LM1-MD) }\end{array}$ & Legitimacy of authority & \\
\hline $\begin{array}{c}\text { "Everybody is now accountable, they understand they have to be accountable, they } \\
\text { understand they have to be decisive. They understand they have to be resilient and they } \\
\text { have to prioritise" (LM2-CM) }\end{array}$ & Relevance & \\
\hline $\begin{array}{l}\text { "It gives them [employees] clarity on what that 'good' looks like.... If I want to do this job, } \\
\text { that's fine too, I don't have to be excellent; but actually, if I really want to be excellent these } \\
\text { are the extra bits I have to do" (LM1-MD) }\end{array}$ & Instrumentality & Consistency \\
\hline $\begin{array}{c}\text { "everybody had oversight of each other's... targets... There are team targets and there } \\
\text { are individual targets and they can track those each day. So, they can see how they're } \\
\text { performing against each other" (LM3-DM) }\end{array}$ & Validity & \\
\hline \multicolumn{3}{|l|}{ "I certainly found that HR did a really good job empowering us to do it" (LM1-MD) } \\
\hline "It was driven out in lots of meetings and lots of discussions" (LM3-DM) & Consistent HRM Messages & \\
\hline $\begin{array}{l}\text { "you do have to reward people for just doing what they're paid to do. And then reward } \\
\text { them more for doing the extra" (LM1-MD) }\end{array}$ & Fairness - distribute justice & Consensus \\
\hline $\begin{array}{l}\text { "it gives them a comfort that how people are measured across the organization is } \\
\text { reasonably consistent" (LM2-CM) }\end{array}$ & Fairness - procedural justice & \\
\hline $\begin{array}{c}\text { "it allows you within your one-to-ones, [to highlight] ... positive feedback in terms of } \\
\text { how they have delivered to the model. You can also equally say ... this is where you're not } \\
\text { delivering. ... You give quality feedback" (LM2-CM) }\end{array}$ & Fairness - interactional justice & \\
\hline $\begin{array}{l}\text { "I think we're all talking the same language now. You know, we all talk about things within } \\
\text { the context of the model, so it does make it that bit easier, you know, we're all talking to } \\
\text { the same themes." (LM2-CM) }\end{array}$ & Agreement & \\
\hline
\end{tabular}

Table 6: Employees' Quotes on Implementing HRM.

\begin{tabular}{|c|c|c|c|}
\hline Example quotes & No. of codes & Meta-features & Main features \\
\hline $\begin{array}{l}\text { "This email goes out and says, 'here's our new model has a read of it and then you were } \\
\text { brought into a workshop and you were put through this workshop" (Employee 2) }\end{array}$ & 8 & Visibility & \multirow{4}{*}{ Distinctiveness } \\
\hline \multirow[t]{2}{*}{$\begin{array}{l}\text { "You had } 80 \% \text { in the middle box and you had } 10 \% \text { in the lower end or whatever way it's } \\
\text { broken down." (Employee 3) }\end{array}$} & 7 & Understandability & \\
\hline & 0 & $\begin{array}{l}\text { Legitimacy of } \\
\text { authority }\end{array}$ & \\
\hline $\begin{array}{l}\text { "I suppose in terms of that model, I suppose there is a level of inflexibility for those who } \\
\text { aren't in a flexible job... so it doesn't really suit somebody who's on a care queue all day } \\
\text { because they don't have an opportunity to probably reach out and do something else. So, } \\
\text { it doesn't give them an opportunity, there is no opportunity for them." (Employee 2) }\end{array}$ & 6 & Relevance & \\
\hline $\begin{array}{l}\text { "Because it directly linked to bonus. And I'm sure it's directly linked to bonuses in a lot of } \\
\text { companies. But it was another opportunity to box people off. And I think then everybody } \\
\text { understood as well that you could only have } 10 \% \text { in a box who were reaching this...we'll } \\
\text { say exceptional." (Employee 2) }\end{array}$ & 8 & Instrumentality & \multirow{3}{*}{ Consistency } \\
\hline $\begin{array}{l}\text { "To the whole objective it has placed high performance as a spoken model, and it has } \\
\text { created a debate and we all know performance matters." (Employee 3) }\end{array}$ & 4 & Validity & \\
\hline $\begin{array}{l}\text { “So, we've had quite a few models coming through. So, I am at a point, and I certainly was } \\
\text { at a point when this model was presented where I was 'oh here we go again, here's another } \\
\text { one." (Employee 2) }\end{array}$ & 2 & $\begin{array}{l}\text { Consistent HRM } \\
\text { Message }\end{array}$ & \\
\hline
\end{tabular}


“[The new model] doesn't give [people on routine work] an opportunity, there is no opportunity for them." (Employee 2)

"I think it's also important to know that - we talk about the calibration piece there. Like, I've witnessed conversations where heads of function have met a person for one twenty minutes on a project and because it's been a very negative interaction they've gone away thinking 'oh that person has to be dropped', without knowing how that person has ever worked in the business." (Employee 4)

"It is, that's fine, but I would say that if you were to honestly have a very honest conversation and take all the nonsense out of it for fear of repercussions or fear of looking bad." (Employee 4)

“I just think sometimes the way it's delivered it's just a repeat message." (Employee 2)

Reciprocally, the senior managers recognize the role of the line managers in ensuring the successful implementation of the HPWS system in the organization. This is reflected in the following quote:

“A lot ultimately depends on a person's manager. ... The success depends a lot

on the quality of the manager or how much they bought into it. How much they

care about doing that kind of stuff. So, one of the challenges we'll always have

in any company is ... you'll have some managers who [are] just ... new

managers, they're just learning to cope with the whole thing, and whether

they're able to really coach and help and bring on the people they

have with them might be difficult for them. You have others who are maybe just

not suited to the role" (SM1-AB).

It is also acknowledged that line managers need to mould the implementation of the HRM model and to tailor it to their team. As SM1-AB notes:

"in terms of how it is implemented and the more meaningful conversations...

about ...the value of what you're doing and what you're contributing and how

it fits with your workloads and all that. So that's where [line] managers really

had to make a big difference".

Similarly, by SM2-EM:

"One of the things that was really interesting was ... there was a bit of a

diagnosis done around what is the challenge in each area. And what

was going on in marketing was very different to business, to technology and finance, and we fixed our own house."

We found that the process of implementing the model in different teams was line manager driven, without any mention of specific consistent supports for line managers in making this happen, perhaps due to senior managers recognizing the differentiated nature of different organizational groups and teams, where a consistent approach would not be optimal.

The variation across line manager performance was noted by senior managers. As SM2-EM states:

"it [the HPWS] allowed managers to call other managers and go 'well

hold on my team are doing that but your team aren't'”.

Similarly, at senior management level the HR Director noted: "They [employees] certainly heard everybody from directors to managers talking about unreasonable ambition, it became a bit of a buzzword probably around the place. ...So, you would hear certain buzzwords out of the model that were more pertinent to some areas than others. But I think it depended on which directorate you were in, which aspect of the model resonated most with you." (HR Director)

On the one hand the HR director acknowledges the variation in the implementation of the HPWS in different departments by different line managers (see above quote), while on the other hand the HR director also appreciates that the aim of the HPWS change program was to: "ignite a different era, a different culture; a different way of thinking about the world and it was to unite people's innate ambition". This shows the complexity of achieving a strong HRM system in practice, where a strong culture and unity within the department needs to be tempered with the requirement for flexibility and agility of different departments with different work outcomes and requirements.

Notably at the line manager level, it was apparent that there was variation in the implementation of the HPWS across departments: "I certainly found that there seemed to be a feeling that people were throwing back to the old model where marking somebody as 'development' was - you don't want that person on your team...It made me a little bit cautious about using that so freely, because I had great people in there that I wanted to encourage their development not see them... outside the door." (LM1-MD) 
The employees agreed: "it's like everything it comes back to the managers" (Employee 2).

In addition, it was evident that not every role could achieve "unreasonable ambition", one of the aims of the new HPWS, again underlining the variation between departments and roles within departments.

The input from the employees to the system was perceived by the employees as not being legitimized:

"what I think is a problem with the performance model in terms of the fairness around it... I still think there's a culture in here of the manager comes along with your rating and that's it... Even though you fill out your objectives mid-year and year-end" (Employee 3).

On the other hand, other employees felt empowered by the new HPWS:

"I now [have] got an actual voice in this model" (Employee 1). This lack of consistency and consensus in how the employees perceived their input was being received in the new HPWS, coupled with the inconsistency in the implementation of the HPWS in different departments, raises a challenge in how organizational justice is perceived by the employees [14] consensus feature. Knowledge workers like fair process: 'When employees don't trust managers to make good decisions or to behave with integrity, their motivation is seriously compromised' [27].

In KIFs, the knowledge workers are the key source for new knowledge generation, which, in turn, leads to the organization's success. Therefore, the employees' input is particularly necessary in KIFs. However, the involvement and realisation of knowledge workers' input into facilitating the successful implementation of a HR strategy was not evident in our analysis. Indeed, at the employee level, some employees felt that the model had already been in place in some departments before its actual directed implementation from senior management.

The following quote reflects this: "But I think before they came in, our Manager kind of had us living it in a way didn't she for a couple of years before that? She was big into the high-performance model and showing off what you're good at and pushing that way. ... [Our manager] had kind of started to embed in us before we even got the official high-performance model." (Employee 3)

In addition, the knowledge workers were very cognisant of the fact that the HPWS was being implemented differently and had different implications across different teams: "we're not doing projects like other people in the business...We've no chance of actually getting up to a 'high' or an 'outstanding' performer... The feeling

is, dependent on your role, sometimes you don't have much opportunity to get above the standard rating which would be seen to be a good performer. Once you go [to a different role] ..., if you're involved in projects for example..., you probably have more opportunity to get up into the higher performance grade." (Employee 3)

\section{Discussion}

The aim of this study was to better understand the line manager's role in the implementation of a new HRM initiative (in our study, a high-performance model - HPWS). Using Bowen and Ostroff's [14] HRM system strength model as our framework, we analyzed the views and experience of senior management team, line manager themselves and front-line employees on the topic of line managers' implementation of HRM. We found support for the role of line managers in actualizing HRM through relaying expectations to employees is paramount, which is consistent with existing findings $[8,12]$.

In addition, we found the inconsistency of approaches between line managers in the organization in our analysis of front-line employee data. In other words, different line managers implement HRM in different ways, lacking the intra-group consistency. This aligns with Kilroy and Dundon's [9] study of the relationship between front line manager types and employee behaviors, showing heterogeneity. As we argued in the beginning of the paper, how line managers implement HRM requires further attention Brewster et al. (2013). Moreover, how line managers' inconsistent implementation affects morale, employee engagement and perceptions of organizational justice requires further research and unpacking.

\section{Scholarly Implications}

This study contributes to HRM research on the line manager's role in HRM strategy implementation in three ways. Firstly, by focusing on how line mangers implement HRM as perceived by multiple stakeholders including the senior management team, the line managers themselves and front-line employees, we provide a more comprehensive report on how variations across internal organizational levels exist and may be problematic. Our findings are consistent with other studies on the increasing important role of line managers in implementing HRM [12]. The multiple stakeholders' views around line managers enable us to better understand the process of line managers' implementing of HRM.

Secondly, we adopt Bowen and Ostroff's [14] conceptualization on HRM system strength to analyze the role and actions of line managers, which impact upon the formation of a strong HRM system. Originally Bowen and Ostroff [14] proposed their HRM system strength framework as a higher-level construct, which provides the basis for organizations to develop strong HRM systems impacting on organizational effectiveness. Understanding how such a strong HRM system is developed is warranted. Building on Bowen and Ostroff [14] HRM system strength, we identified the detailed actions taken by the line managers in order to foster a strong HRM system and compared this with the information we received from the detailed interviews. By doing so, we contribute to the HRM system strength research by providing a useful tool on the HRM implementation via line managers. 
From our case study, we found that intra-level variations, i.e. different line managers' implementation of a change initiative in different ways (that is, inconsistency), influence the perception of line managers' successful implementation of an HRM system across three levels (senior management, line management, knowledge workers reporting to line managers). We therefore propose a new and important feature which is the consistency across line managers into the HRM system strength model, which advances our current knowledge about HRM system strength. This suggests that future studies on HRM system strength need to consider these inter-team variant features.

In terms of methodology, our study adopts a qualitative single case study using multiple stakeholders, which enriches existing HRM studies, where quantitative survey methods (more cross-sectional design) and interviews with line managers only are dominant. Our study differs from existing quantitative methods which use complex equations to calculate the interrater agreement in order to capture the shared and collective climate [50]. Qualitative research design enables us to explore what is happening and, more importantly, why. It presents the perceptions across organizational levels, permitting a comprehensive overview of HRM system strength as experienced by the multiple respondents. Rather than simply asserting which dimensions were prevalent across levels in the organization, the qualitative study enabled us to unpack, understand, and explain where shortcomings were apparent.

Finally, this study was conducted in the knowledge intensive context in a specific country context, namely Ireland. It contributes to our understanding of HRM in KIFs by examining the line manager's implementation of HRM. KIFs are important for the development of the knowledge-based economy, but the HRM research in KIFs is limited compared to the large volume of research conducted on manufacturing firms [51-54] or more routinized service firms such as banks [55] and call centres [56]. In the existing studies looking at HRM in KIFs [57-60], a survey method was commonly used. Quantitative research can fail to gain a real understanding of the specific workings of HRM systems from the initial phases of system design to implementation, which can, however, be addressed by using qualitative research.

This proffers a great chance for qualitative research to enrich our knowledge about, not only what HRM practices are important for KIFs, but also how they are implemented successfully to lead the employees to align their individual goals with organizational goals. The findings in our study provide useful insights for KIFs, but may also be useful for a much wider range of contexts such as the service sector that is not limited to the resource of knowledge Similarly, while our case study focuses on a KIF in Ireland, other studies may compare our findings across national contexts, in order to further unpack the Bowen \& Ostroff [14] HRM system strength construct in different contexts [50].

In our study, given the context of the KIF, the role of individual employees and individual contributors appears under-explored.
The voice of the individual contributor about the change management process of the HPWS that was introduced in the case organization was not reflected upon by the other levels in the organization. We suggest this oversight is relevant for organizations, particularly KIFs that are constantly striving to increase competitiveness. To promote a climate of consistency, the voice of individual contributors and employees needs to be acknowledged and integrated in a more reflexive way within the HPWS implementation process.

Given the context of KIFs, it is important to ensure malleability of the change process and agility to match the process with the context and individuals involved. In other words, both a best fit and best practice approach is required, in line with the bundling of HRM practices to specific departments and employee needs, cognisant of the cross-over effect this may have on other departments, comparing their work inputs and reward outputs internally. Evans \& Davis's [61] model which proposed the relevance of internal social structures in the performance outcomes of high-performance work systems is important here.

\section{Implications for Managers}

Our study appreciates the senior managers' promotion of a change management initiative (e.g. introducing a new HPM system) and the HR manager's role in working with senior managers and other human resources in the organization to bring about the new practices [62-65]. This importance of these roles was apparent in our findings. The support of a change initiative by senior management is crucial in ensuring buy-in from others in the organization. While the literature has emphasized the line manager's role in the implementation of HRM practices, the directional and exemplary influence of senior management cannot be underestimated. However, that alone is not enough.

The role of front-line employees, the primary subjects of the new high-performance management system, in providing feedback and insight to the system may be under-appreciated and/or ignored by the other levels in the organization. Indeed, a top-down - rather than a reflexive, top-down/bottom-up - change management implementation process was apparent in our study. We question this lack of inclusion of front-line knowledge workers in the implementation and feedback process of a new HPWS, particularly one that directly affects them. There are lessons for practitioners which our study has brought to light. First, HRM professionals, who are aware of the important role of line managers in promoting a strong HRM system in the organization, need to recognize and develop measures to counter the variation in line manager's implementation processes, depending on the respective experience, skillset and functional area of the line managers in question. Line managers need to implement HRM in a distinctive, consistent and consensual way to develop HRM strength [14], where employees share collective perceptions of HRM within the organization.

Therefore, in implementing HRM practices, HRM professionals need to pay particularly close attention to the promoting stage 
among line managers, where communication and consultation with line managers is pivotal. This is supported by our finding that line managers experience less surety in terms of rationalizing why HRM models are required and being implemented. For line managers, they need to work closely with HRM professionals to share their opinions on whether the intended HRM practices are relevant to their direct employees' needs. In communicating with employees, line managers need to take extra care with interactional justice and demonstrate that they are in accord with the HRM department and top management, particularly in KIFs where employees are aware of how other teams are being managed [66-69].

\section{Limitations and Future Research}

This study was exploratory and examined the implementation of a high-performance model. It aimed to better understand the process of line manager implementation of a strong HRM system. It contributes to theory and practice in many ways, primarily in providing a more nuanced understanding of the line manager's role in the implementation of a strong HRM system in a knowledgeintensive firm. Nonetheless it does have some limitations. It is based on a single organization operating in one industrial sector, on a small sample size, in a specific country context [70-73].

The paper set out to present collective insights across organizational levels, but we acknowledge that it is difficult to generalize these findings. As was presented in both the literature review and the findings from the interviews conducted, the highperformance model is multidimensional, and it is influenced by internal and external factors. Its success is gauged not in the short-term but in the long-term. Longitudinal studies including diary entries across organizational levels over the implementation period of a new HRM model would be very useful in further research, in providing detailed data of the nuances across organizational levels over time [74-76].

The data for our study was collected entirely from one organization. Although the richness of the qualitative data facilitated unpacking the line manager's role as perceived across organizational levels, the findings shared here need to be empirically tested in a larger sample and other organizations/ KIFs to see if they can be generalized. In the data collection stage of the study, the sample was selected based on the first author's own network which might have resulted in respondents' bias. However, the quotes and interviews that were analyzed did show heterogeneity across the perceptions of the HPWS implementation. A future research avenue would be to further consider our extension to the Bowen \& Ostroff [14] model (including a crosslevel, intra-level and looped approach) quantitatively, through deliberately separating out different levels [77].

We acknowledge that the interview data from the case organization considered in this paper is limited, due to the small quantity of interviews conducted. However, small sample sizes are usual in qualitative research and this research undertaking sought to consider HRM system strength components [14] through coding the interview data with this model in mind. While this paper has drawn on only a limited number of interviews with employees across the organizational levels at the knowledge intensive case firm, it does provide a snapshot across organizational levels of how key players in a change initiative experienced the process. Future research studies could focus on a level and gather more interviews at that level in order to develop further knowledge about how a change initiative, the introduction of a high-performance model, is perceived and implemented at a level within the organization [78-81].

In qualitatively coding the data under the Bowen \& Ostroff [14] features, it became increasingly evident to the researchers that the boundaries between some of the features and metafeatures according to Bowen \& Ostroff's [14] framework overlap [82]. There were quotes that were coded under both visibility (as everybody was talking about it) and understanding (which aspect of the model resonated with the individual employee). While this may be considered a limitation, the authors did not find that it limited the analysis, but rather that it supported the complexity and comprehensiveness of the model. As outlined earlier in this section, longitudinal studies on the HRM system strength construct in relation to the introduction of HRM initiatives within organizations would be particularly interesting for further research in this area. Such a study could further unpack the HRM system strength model in practice $[83,84]$.

\section{Conclusion}

This study extends our understanding of the line manager's role in HRM implementation via a single case study of a large knowledge intensive firm based in Ireland. Employing Bowen and Ostroff's [14] HRM system strength model, this study qualitatively unpacks how line managers implement HRM initiatives, as perceived by senior management, frontline employees and the line managers themselves. Line managers' implementation of HRM is found to be aligned with all features of a strong HRM system.

Both senior management team members and front-line employees (knowledge workers) in our study emphasized the importance of line managers' implementation of HRM in promoting a strong HRM system. However, concerns are raised about the inconsistency of implementation practices among line managers. How organizations, senior managers and HRM professionals support and develop line managers consistently in order to lead to employees' shared perceptions and experience of organizational HRM is an interesting and important question for future research, particularly in the context of KIFs where agility and flexibility across departments is essential.

\section{References}

1. Ferguson, K, Reio Jr, TG. (2010) Human resource management systems and firm performance. Journal of Management Development 29(5): 471-494.

2. Guest, DE (2011) Human resource management and performance: still searching for some answers. Human Resource Management Journal 21(1): 3-13. 


\section{Annals of Social Sciences \& Management studies}

3. Meena, K, Vanka, S (2017) Developing an empirical typology of diversity-oriented human resource management practices. Journal of Management Development 36(7): 915-929.

4. Obedgiu, V (2017) Human resource management, historical perspectives, evolution and professional development. Journal of Management Development 36(8): 986-990.

5. Wright, P, Nishii, LH (2013) Strategic HRM and Organizational Behavior: Integrating Multiple Levels of Analysis. In D. Guest, J. Paauwe, and P. Wright (Eds.), HRM and Performance: Achievements and Challenges, 97-110. Chichester: John Wiley \& Sons. England.

6. Jiang, K, Takeuchi, Lepak, DP, et al. (2013) Where Do We Go from Here? New Perspectives on the Black Box in Strategic Human Resource Management Research. Journal of Management Studies 50(8): 1448-1480.

7. Bondarouk, T, Kees Looise, J, Lempsink (2009) Framing the Implementation of HRM Innovation: HR Professionals vs Line Managers in a Construction Company. Personnel Review 38(5): 472-491.

8. Bos-Nehles, AC, Van Riemsdijk, MJ, Kees Looise (2013) Employee Perceptions of Line Management Performance: Applying the AMO Theory to Explain the Effectiveness of Line Managers' HRM Implementation. Human Resource Management 52(6): 861-877.

9. Kilroy, J, Dundon, T (2015) The Multiple Faces of Front-Line Managers: A Preliminary Examination of FLM Styles and Reciprocated Employee Outcomes. Employee Relations 37(4): 410-427.

10. Den Hartog, DN, Boon, Verburg, Croon, et al. (2013) HRM, Communication, Satisfaction, and Perceived Performance A Cross-Level Test. Journal of Management 39(6): 1637-1665.

11. Ulrich, D (2009) HR Transformation. Chicago: McGraw-Hill, USA.

12. Whittaker, S, Marchington, M (2003) Devolving HR Responsibility to the Line: Threat, Opportunity or Partnership? Employee Relations 25(3): 245-261.

13. U Irich, D, Brockbank, W (2005) The HR Value Proposition. Boston Mass.: Harvard Business Review, USA.

14. Bowen, DE, Ostroff, C (2004) Understanding HRM-firm Performance Linkages: The Role of the 'strength' of the HRM System. Academy of Management Review 29(2): 203-221.

15. Bos-Nehles, AC, Bondarouk, TV (2012) How Line Management Intentions Become Employee Perceptions: Conceptualization of the Role of Frames in HRM System Strength. In: XIII Workshop dei Docenti e dei Ricercatori di Organizzazione Aziendale (WOA 2012), Verone Italy.

16. Alvesson, M (2000) Social Identity and The Problem of Loyalty in Knowledge-Intensive Companies. Journal of Management Studies 37(8): 1101-1124.

17. Fu, N (2015) The Role of Relational Resources in the Knowledge Management Capability and Innovation of Professional Service Firms. Human Relations 68(5): 731-764.

18. Swart, J, Kinnie, N (2003) Sharing Knowledge in Knowledge-intensive Firms. Human Resource Management Journal 13(2): 60-75.

19. George, Zahra, Wheatley, KK, Khan, et al. (2001) The Effects of Alliance Portfolio Characteristics and Absorptive Capacity on Performance: A Study of Biotechnology Firms. The Journal of High Technology Management Research 12(2): 205-226.

20. Colquitt, Conlon, Wesson, Porter, CO, et al. (2001) Justice at the Millennium: A Meta-Analytic Review of 25 Years of Organizational Justice Research. Journal of Applied Psychology 86(3): 425-445.

21. Adams, JS (1965) Inequity in Social Exchange. Advances in Experimental Social Psychology 2: 267-299.

22. Leventhal, GS (1980) What Should Be Done with Equity Theory?, In KJ Gergen, MS Greenberg, RH Willis (Eds.), Social Exchange 27-55.
23. Leventhal, GS, Karuza, Fry, WR, et al. (1980) Beyond Fairness: A Theory of Allocation Preferences. In G. Mikula (ed). Justice and Social Interaction, pp. 167-218.

24. Greenberg, J (1990) Employee Theft as a Reaction to Underpayment Inequity: The Hidden Cost of Pay Cuts. Journal of Applied Psychology 75(5): 561.

25. Heffernan, M, Dundon, T (2016) Cross-level effects of high-performance work systems (HPWS) and employee well-being: the mediating effect of organisational justice. Human Resource Management Journal, 26(2): 211-231.

26. Shen, J, Benson, Huang, B (2014) High-Performance Work Systems and Teachers' Work Performance: The Mediating Role of Quality of Working Life. Human Resource Management 53(5): 817-833.

27. Kim, W, Mauborgne, R (2003) Fair Process: Managing in the Knowledge Economy. [online] Harvard Business Review. USA.

28. Gerstner, CR, Day, DV (1997) Meta-Analytic Review of Leader-member Exchange Theory: Correlates and Construct Issues. Journal of Applied Psychology 82(6): 827-844.

29. Harney, B, Jordan, C (2008) Unlocking the Black Box: Line Managers and HRM-Performance in a Call Centre Context. International Journal of Productivity and Performance Management 57(4): 275-296.

30. Purcell, J, Hutchinson, S (2007) Front-line Managers as Agents in the HRM-performance Causal Chain: Theory, Analysis and Evidence. Human Resource Management Journal 17(1): 3-20.

31. Tuckey, MR, Bakker, AB, Dollard, et al. (2012) Empowering Leaders Optimize Working Conditions for Engagement: A Multilevel Study. Journal of Occupational Health Psychology 17(1): 15-27.

32. Greenhaus, JH, Parasuraman, Wormley, WM (1990) Effects of Race on Organizational Experiences, Job Performance Evaluations, and Career Outcomes. Academy of Management Journal 33(1): 64-86.

33. Thompson, M, Heron, P (2005) The Difference a Manager Can Make: Organizational Justice and Knowledge Worker Commitment. The International Journal of Human Resource Management 16(3): 383-404.

34. McDermott, AM, Conway, Rousseau, Flood, et al. (2013) Promoting Effective Psychological Contracts through Leadership: The Missing Link between HR Strategy and Performance. Human Resource Management 52(2): 289-310.

35. Brower, HH, Schoorman, FD, Tan (2000) A Model of Relational Leadership: The Integration of Trust and Leader-member Exchange. The Leadership Quarterly 11(2): 227-250.

36. Caldwell, Hayes, Bernal, Karri, R (2008) Ethical Stewardship-Implications for Leadership and Trust. Journal of Business Ethics 78(1-2): 153-164.

37. Conway, E, Monks, K (2011) Change from below: The Role of Middle Managers in Mediating Paradoxical Change. Human Resource Management Journal 21(2): 190-203.

38. Stake, RE (1994) Case Studies. In N Denzin, YS Lincoln (Eds) Handbook of Qualitative Research 236-247. Thousand Oaks, California: Sage, USA.

39. Stake, RE (1998) Case Studies. In N. Denzin, Lincoln. YS (Eds) Strategies of Qualitative Inquiry, 86-109. Thousand Oaks, California: Sage, USA.

40. Guba, E, Lincoln, Y (1982) Epistemological and Methodological Bases of Naturalistic Inquiry. ECTJ 30(4): 233-252.

41. Bergadaa, M (1990) The Role of Time in the Action of the Consumer. Journal of Consumer Research 17(3): 289.

42. Robson, C (2011) Real world research. (1 $1^{\text {st }}$ edn). Chichester, West Sussex: Wiley, England.

43. Easterby-Smith, M, Thorpe, Lowe, A (2002) Management Research: An Introduction, (2 $2^{\text {nd }}$ edn). London: Sage, England. 


\section{Annals of Social Sciences \& Management studies}

44. McCracken, G (1988) The Long Interview: Qualitative Research Methods. Beverly Hills: Sage, USA.

45. Mason, J (2002) Qualitative Researching, (2 ${ }^{\text {nd }}$ edn). Sage, London.

46. Kvale, S, Brinkmann, S (2009) Interviews: Learning the Craft of Qualitative Research Interviewing. Sage: London.

47. Smith, J, Larkin, M, Flowers, P (2008) Doing interpretative phenomenological analysis. ( $1^{\text {st }}$ edn). Sage, London.

48. Ritchie, J, Spencer, L (1994) Qualitative data analysis for applied policy research. In: A. Bryman and B. Burgess, ed., Analyzing qualitative data, $\left(1^{\text {st }}\right.$ edn). London: Routledge, pp. 173-194.

49. Ritchie, Spencer, Bryman, Burgess, RG (1994) Analysing Qualitative Data. Routledge, London.

50. Farndale, E, Sanders, K (2017) Conceptualizing HRM System Strength Through a Cross-Cultural Lens, The International Journal of Human Resource Management 28(1): 132-148.

51. Datta, DK, Guthrie, JP, Wright et al. (2005) Human Resource Management and Labor Productivity: Does Industry Matter. Academy of Management Journal 48(1): 135-145.

52. Gant, Ichniowski, C, Shaw, K (2002) Social Capital and Organizationa Change in High-Involvement and Traditional Work Organizations. Journal of Economics and Management Strategy 11(2): 289-328.

53. Takeuchi, Lepak, DP, Wang, Takeuchi, et al. (2007) An Empirical Examination of the Mechanisms Mediating between High-Performance Work Systems and the Performance of Japanese Organizations. Journal of Applied Psychology 92(4): 1069.

54. Takeuchi, R, Chen, Lepak, DP (2009) Through the Looking Glass of a Social System: Cross-Level Effects of High-Performance Work Systems on Employees' Attitudes. Personnel Psychology 62(1): 1-29.

55. Liao, Toya, Lepak, DP, Hong, et al. (2009) Do They See Eye to Eye? Management and Employee Perspectives of High-Performance Work Systems and Influence Processes on Service Quality. Journal of Applied Psychology 94(2): 371-391.

56. Batt, R (2002) Managing Customer Services: Human Resource Practices, Quit Rates, and Sales Growth. Academy of Management Journal 45(3): 587-597.

57. Collins, CJ, Smith, KG (2006) Knowledge Exchange and Combination: The Role of Human Resource Practices in the Performance of High-Technology Firms. Academy of Management Journal 49(3): 544-560.

58. Chow, HIS, Gong, Y (2010) The Linkage of HRM and Knowledge-Related Performance in China's Technology-Intensive Industries. The International Journal of Human Resource Management 21(8): 1289-1306.

59. Fu, N (2013) Exploring the Impact of High-Performance Work Sys tems in Professional Service Firms: A Practices-Resources-Uses-Performance Approach. Consulting Psychology Journal: Practice and Research 65(3): 240-257.

60. Fu, Flood, P Bosak, J Morris, O’Regan, et al. (2013) Exploring the Performance Effect of High Performance Work System on Service Supply Chain in Professional Service Firms. Supply Chain Management: An International Journal 18(3): 292-307.

61. Evans, WR, Davis, WD (2005) High-Performance Work Systems and Organizational Performance: The Mediating Role of Internal Social Structure. Journal of Management 31(5): 758-775.

62. Armstrong, M, Taylor, S (2014) Armstrong's Handbook of Human Resource Management Practice. Kogan Page Publishers: London, UK.

63. Becker, B, Huselid, MA (1998) High Performance Work Systems and Firm Performance: A Synthesis of Research and Managerial Implications. In G. R. Ferris (Ed.), Research in Personnel and Human Resource Management, 16, 53-101. JAI Press: Greenwich, England.
64. Beer, M, Eisenstat, R, Foote, N (2009) High commitment, high performance. ( $1^{\text {st }}$ edn). San Francisco, CA: Jossey-Bass, Spain. pp.19, 29, 40, 213.

65. Chen, Y, Hsu, Yip, F (2011) Friends or Rivals: Comparative Perceptions of Human Resource and Line Managers on Perceived Futoure Firm Performance. The International Journal of Human Resource Management 22(8): 1703-1722.

66. Chen, CJ, Huang, JW (2009) Strategic Human Resource Practices and Innovation Performance-The Mediating Role of Knowledge Management Capacity. Journal of Business Research 62(1): 104-114.

67. CIPD (2014) Sustainable Organization Performance - Factsheets - CIPD.

68. Combs, Liu, Hall, Ketchen, D (2006) How Much do High-Performance Work Practices Matter? A Meta-Analysis of their Effects on Organizational Performance. Personnel Psychology 59(3): 501-528.

69. Delery, JE, Doty, DH (1996) Modes of Theorizing in Strategic Human Resource Management: Tests of Universalistic, Contingency, and Configurational Performance Predictions. Academy of Management Journal 39(4): 802-835.

70. Fu, Flood, Bosak, Morris, O’Regan, et al. (2015) How Do High Performance Work Systems Influence Organizational Innovation in Professional Service Firms? Employee Relations 37(2): 209-231.

71. Guthrie, JP (2001) High-Involvement Work Practices, Turnover, and Productivity: Evidence from New Zealand. Academy of Management Journal 44(1): 180-190.

72. Huselid, MA (1995) The Impact of Human Resource Management Practices on Turnover, Productivity, and Corporate Financial Performance. Academy of Management Journal 38(3): 635-672.

73. Lepak, Hui Liao, Yunhyung Chung, Erika E, Harden, et al. (2006) A Conceptual Review of Human Resource Management Systems in Strategic Human Resource Management Research. In JJ Martocchio (Ed.), Research in Personnel and Human Resources Management 25: 217-271.

74. MacDuffie, JP (1995) Human Resource Bundles and Manufacturing Performance: Organizational Logic and Flexible Production Systems in the World Auto Industry. Industrial \& Labor Relations Review 48(2): 197-221.

75. Messersmith, JG, Guthrie, JP (2010) High Performance Work Systems in Emergent Organizations: Implications for Firm Performance. Human Resource Management 49(2): 241-264

76. Nishii, LH, Lepak, DP, Schneider, et al. (2008) Employee Attributions of the 'why' of HR Practices: Their Effects on Employee Attitudes and Behaviors, and Customer Satisfaction. Personnel Psychology 61(3): 503-545.

77. Ostroff, C, Bowen, DE (2000) Moving HR to a Higher Level: HR Practices and Organizational Effectiveness. In KJ Klein, SWJ Kozlowski (Eds.), Multilevel Theory, Research, and Methods in Organizations: Foundations, Extensions, and New Directions, 211-266. San Francisco, CA, US: Jossey-Bass, USA

78. O'Connor, EP, Crowley-Henry, M (2017) Exploring the Relationship between Exclusive Talent Management, Perceived Organizational Justice and Employee Engagement: Bridging the Literature. Journal of Business Ethics. pp. 1-15.

79. Paauwe, J (2009) HRM and Performance: Achievements, Methodological Issues and Prospects. Journal of Management Studies 46(1): 129142.

80. Pate, J, Martin, G, Staines et al. (2000) Exploring the relationship between psychological contracts and organizational change: a process model and case study evidence. Strategic Change 9(8): 481-493.

81. Richard, OC, Johnson, NB (2001) Strategic Human Resource Management Effectiveness and Firm Performance. International Journal of Human Resource Management 12(2): 299-310. 


\section{Annals of Social Sciences \& Management studies}

82. Swart, J, Kinnie, N (2010) Organizational Learning, Knowledge Assets and HR Practices in Professional Service Firms. Human Resource Management Journal 20(1): 64-79.

83. Van Dijk, R, Van Dick, R (2009) Navigating organizational change: change leaders, employee resistance and work-based identities. Journal of Change Management 9(2): 143-163.
84. Youndt, MA, Snell, SA, Lepak, et al. (1996) Human Resource Management, Manufacturing Strategy, and Firm Performance. Academy of Management Journal 39(4): 836-866.

\begin{tabular}{|l|}
\hline \multicolumn{1}{|c|}{$\begin{array}{c}\text { your next submission with Juniper Publishers } \\
\text { will reach you the below assets }\end{array}$} \\
- Quality Editorial service \\
- Swift Peer Review \\
- Reprints availability \\
- E-prints Service \\
- Manuscript Podcast for convenient understanding \\
- Global attainment for your research \\
- Manuscript accessibility in different formats \\
( Pdf, E-pub, Full Text, Audio) \\
- Unceasing customer service \\
Track the below URL for one-step submission \\
https://juniperpublishers.com/online-submission.php
\end{tabular}

